CATALAN REVIEW

Catalan Review

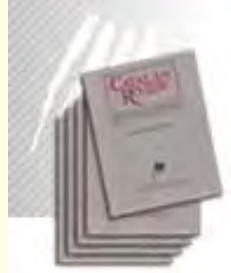

You are accessing the Digital Archive of the Catalan Review Journal.

By accessing and/or using this Digital Archive, you accept and agree to abide by the Terms and Conditions of Use available at http://www.nacs-

catalanstudies.org/catalan_review.html

Catalan Review is the premier international scholarly journal devoted to all aspects of Catalan culture. By Catalan culture is understood all manifestations of intellectual and artistic life produced in the Catalan language or in the geographical areas where Catalan is spoken. Catalan Review has been in publication since 1986 .
NORTH

AMERICAN

CATALAN

SOCIETY
Esteu accedint a l'Arxiu Digital del Catalan Review

A l' accedir i / o utilitzar aquest Arxiu Digital, vostè accepta i es compromet a complir els termes i condicions d'ús disponibles a http://www.nacs-

catalanstudies.org/catalan_review.html

Catalan Review és la primera revista internacional dedicada a tots els aspectes de la cultura catalana. Per la cultura catalana s'entén totes les manifestacions de la vida intel lectual i artística produïda en llengua catalana o en les zones geogràfiques on es parla català. Catalan Review es publica des de 1986.

Folklore and politics in Catalonia. Traditional popular activities as symbolic expressions of nationalism Curt Witilin

Catalan Review, Vol. VII, number 1 (1993), p. 103-122 


\section{FOLKLORE AND POLITICS IN CATALONIA. TRADITIONAL POPULAR ACTIVITIES AS SYMBOLIC EXPRESSIONS OF NATIONALISM}

\section{CURT WITTLIN}

In 1990, Catalonia celebrated the "Year of the Millenium", remembering a rather obscure document in which Count Borrell II declares himself independent from his Frankish overlord.' 1991 was the "Year Joan Amades", honoring Catalonia's, most endearing folklorist. ${ }^{2} 1992$ was the "Year of the Olympics", which was taken advantage of to show the world -in Catalan! - that Barcelona is more than just "a big city in Spain". ' During this year's centenary, Catalonia hopes to raise the Art World's consciousness that Joan — not Juan-Miró was a Catalan, not a "Spanish", artist. Some journalists have criticised the Generalitat for spending too much money on such projects to advertise Catalan history, culture and vitality. They have a point, of course, but most citizens think their country, Catalonia, deserves to be better known and to be recognized as Spain's most progressive region, and that they should be granted the right to affirm their individuality as a distinct society.

' See La commemoració del Mil.lenari de Catalunya, Barcelona: Generalitat, 1990, with lists of activities, photographs of ceremonies and edition of speeches.

${ }^{2}$ See the list of the year's activites in the 1991 Suplement to the Generalitat's magazine "Culturas. The volume El món de Joan Amades, edited by the "Centre de Documentació i Recerca de la Cultura Tradicional i Popular", offers on pp. III-246 a biography and a bibliography of Amades, followed by the catalogue of the memorial exhibit in Barcelona.

${ }^{3}$ In 1990, as vol. 3 of the series Som $i$ serem ("We are and will always be", that is, a Nation), the Generalitat published the picture book by Josep Puigjaner Conèxer Catalunya in Catalan, Spanish, English, German and French editions. On p. 276 we read (our translation): "The Olympics are a test not only for Barcelona, but for the whole country. Catalonia will have to prove its organizational know-how... and its consistència nacionab. 
In these pages we will describe how for over one hundred years Catalan nationalism has found its rallying symbols in activities which anthropologists and sociologists classify as "folklore" or "popular culture». We will observe in more detail how associations of hikers, singers and dancers were founded in the second half of the nineteenth Century, remained active up to the Civil War, and have now regained their former strength, after adapting to changed social circumstances. People, of course, engage in such activities for reasons other than patriotism. Hiking may be just a physical exercise, or an act of faith in the case of a pilgrimage. But we will see that in Catalonia most organized popular activities build on a pervasive ideological basis established at the beginning of the Renaixença, the "Rebirth" of Catalan national consciousness around 1850. During Franco's dictatorship, clubs for hikers, dancers or singers came in some respect to resemble resistance movements. Given the potential for political abuse of organized leisure activities, it is not surprising that modern European governments prefer to remain passive, not wanting to be seen supporting ideologically charged popular activities. Two recently established para-governmental institutions, however, show that Catalonias Generalitat recognizes that its duty to preserve the region's achievements of the past and prepare it for the challenges of her future must include a folkloric dimension. On the other hand, university research on folklore remains blocked by the reluctance of academics to show interest in activities traditionally studied mostly by amateurs, by their fear of compromising themselves politically, and by sterile descussions about the division of the field among folklorists, anthropologists, ethnographers and socioligists.

We cannot extend the present study to cover also the Balearic Islands and Valencia. As for Catalonia, we will concentrate on Barcelona, where most of the activities described in these pages got started. It is difficult to be up-to-date on publications from the major towns of Catalonia's comarques, such as Berga, la Seu d'Urgell, Tremp, ${ }^{4}$ Es-

4 Where the "Centre d'Estudis del Pallars" has published the journal "Collegats" since 1987 . 
terri d'Aneu, Ripoll, Lleida, ${ }^{6}$ Olot, Vic, Solsona, ${ }^{7}$ Figueres, Girona, Reus, ${ }^{\mathrm{B}}$ and Tarragona."

\section{THE «RENAIXENÇA» AND THE BEGINNINGS OF ASSOCIATIONS FOR HIKERS, SiNGERS AND DANCERS}

It is a well-known fact that the systematic study of folklore has its roots in the romantic myth of the "noble peasant" as depository of centuries of wisdom, untainted by the decadent urban "élites"..$^{10}$ The brothers Grimm gathered folksongs and folktales because they believed them to go back to pre-Christian Arian roots. In Catalonia too, plans for collecting oral traditions and rural artifacts were motivated by the desire to uncover the timeless unique Catalan character, the relics of a Catalan race. " As elsewhere, interest was at first of a literary nature,

5. Where local folklorists have started in 1990 the journal "Arnicas.

${ }^{6}$ Where Virgili and Pagès have printed, since 1987 , eleven volumes on folklore, such as Joan Bellmunt, Fets, costums i llegendes: Vall d'Aran, 1991.

7 Which has an active "Grup de recerca folklórica».

${ }^{8}$ Where the "Centre de documentació sobre cultura popular Carrutxa", since 1980, has continued the strong local folkloric tradition. See for example Josep Lluís Savall, El vocabulari dels pescadors de Cambrils, Associació d'Estudis Reusencs, 1991.

9 Where the University publishes the journal aArxiu d'Etnografia de Catalunyas. (three volumes so far); see Pujadas 1983, Pp. 74-86 (with bibliography), and Llopart 1980. The study by Maria Teresa Montaña i Martí, Etnografia de l'ofici d'escombrer a Tarragona (on streetsweepers and their tools), Barcelona 1987, shows that old-fashioned methods still give excellent results. Since 1986 Edicions El Mèdol has published the journal "Terregadas; in 1990 they printed Jaume Bori i Roqué, Recull de folklore del Montsant.

10 See G. Cocchiara, The History of Folklore. The introduction of romantic folklore to Catalonia is described, with a certain repetitiousness, by Ll. Prats, El mite de la tradició popular, Ll. Calvo Calvo, "El Arxiu d'Etnografia i Folklore de Catalunya", chaps. 2-4, and in articles by Llobera 1983 , and by Prat 1985 and 1988.

II Notice the contrast between Catalonia, where the reborn nation was to be built on myths believed to be already there since time immemorial, and the United States where the myths and symbols of the new nation were created as the place was settled. See Elise Marienstras, Les mythes fondateurs de la nation américaine, Paris 1977. As for The Invention of Tradition in Scotland, Wales, the British colonies, and other countries, 
and the early collectors of country songs and tales did not hesitate to change their texts for stylistic or moralistic reasons. Manuel Milà $\mathrm{i}$ Fontanals ${ }^{12}$ considered his heavily annotated Observaciones sobre la poesia popular, con muestras de romances catalanes inéditos, published in 1853, a contribution to comparative literature. But when in 1882 he printed an expanded version of parts of the Observaciones under the title Romancerillo catalán, he left out the academic apparatus, having gained confidence that these songs and ballads could be revived. Marià Aguilót ${ }^{19}$ too collected folksongs, considering them living proof of the cultural unity of Catalonia, the Balearic Islands and Valencia.

These early publications of folkloristic texts were perused by candidates for prizes at the Jocs Florals, reorganized in $1859,{ }^{14}$ whether for poetic inspiration, or as models for spelling. The literary value of the poems submitted was often low, but the Jocs Florals were appreciated as an occasion to celebrate Catalan history in a patriotic ritual for the upper class. They contributed to the Catalan language being once again considered worthy of use in literature, but they remained an urban phenomenon, the pastime of a social class which otherwise did not resist the Castilianization of its lifestyle and thinking. The true Catalan spirit was thought to have been preserved better by peasants, shepherds, fishermen and rural artesans, illiterate but wise.

To discover the true and unique nature of Catalan-ness, everyone, from true patriots to armchair ideologues, urged anyone go out into the country and explore the basic elements of the Catalan Nation - the living common language, the coherent human geography, the relics of a glorious past in the ruins of castles and convents - and to discover the basis for a great new beginning in rural churches and hermitages,

see the proceedings of a convention with this title edited by Eric J. Hobsbawm, Cambridge 1983 (Catalan translation, Vic 1988).

${ }_{12}$ See index to Manuel Jorba, L'obra critica i erudita de Manuel Milà i Fontanals, Barcelona-Montserrat 1984 .

${ }^{13}$ See J. Massot 1980 and I98I, and, for a description of the avatars of Milà's Obra del Cançoner Popular de Catalunya, Artís 1986.

${ }^{14}$ See Josep Miracle, La restauració dels Jocs Florals, Barcelona 1960, and Josep Faulí, Els Jocs Florals de Barcelona, Barcelona 1980. 
rich country estates (cases pairals) and the traditional economic structure of handicraft and trade. The movent of excursionisme cientific started around 1876 with the founding of several hiking clubs, first in Barcelona, then in other cities as well. ${ }^{\text {is }}$ While excursionism is obviously related to other activities which have their roots in romantic notions of self-improvement through naturism, vegetarianism and so on, the importance it gained for Catalan national consciousness, and the enduring strength of its symbolic value, are unparalleled elsewhere. Sunday outings, facilitated by the new railways and the 1904 Lord's Day's Act, attracted a larger and wider fellowship than the Jocs Florals, and this all year long. Everybody was invited by the movement's leaders to do "scientific" work by asking country folk for place names or descriptions of their work, by making sketches of ruins and hermitages, by collecting goigs, ${ }^{16}$ by photographing roadside crosses. ${ }^{17}$ The newsbulletins of the various clubs (for example the "Annuari de l'AEC" and the "Memories de l'ACE", first published in 1882 and 1884 , respectively) are full of such materials. Lexical items reported in these newsletters were later incorporated in their respective Catalan dictionaries by Antoni Griera and Antoni Alcover, both much interested in folklore. In certain associations, «research" was probably secondary to less advertised goals, such as the socialization of working class children in a conservative catholic context, or in secularistic clubs such as the scouts. But even in such cases, instilling l'amor a la Terra ${ }^{8}$ and a consciousness

"s See the over nine hundred pages of history of the movement by J. Iglésies in the Enciclopèdia de l'excursionisme. See also Torres 1979, Ramon i Vidal 1983, Congrès 1982.

${ }^{16}$ Goigs are illustrated one-page prints with the saint's hymn which can be picked up at the relevant sanctuary. Souvenirs of excursions, they become collectors' items. See, for instance, Xavier Garcia, Ricard Vives i Sabaté, una vida per als goigs, Vilanova i la Geltrú: Gran penya, I991; or Osvald Cardona, La tradició literària i els goigs de Sant Ramon de Penyafort, Vilafranca del Penedès: Museu, 1990.

${ }^{17}$ The comparison of two books, one from 1919 by Gudiol and the other from 1983 by Bastardas, shows the synergy resulting from combining the love of the outdoors with the patriotic desire to preserve Catalonia's artistic and religious heritage. Both authors visited the whole country taking pictures and measurements of roadside crosses, Bastardas adding 407 pictures to Gudiol's collection.

${ }_{18}^{18}$ From the Bylaws of the "Centre Excursionista" from Terrassa, 19ro, par. I. 
of the linguistic, historical, spiritual and geographic unity of Catalonia, was a major objective.

Other research was done by correspondence. Even in the case of legal folklore, use of rural informants was considered possible. The two booklets published by the Mancomunitat (the administration of the combined four Catalan provinces between 1914 and 1929) based on materials thus collected ${ }^{19}$ seem to take for granted that investigation of traditional law would show that "Catalan customs are the same in all of Catalonia, except for merely accidental particularitiesn (introduction).

The questionnaire on traditional legal customs was only one of twenty-two mailed out to hundreds of respondents by the "Arxiu d'Etnografia i Folklore de Catalunya" after it was founded in $1915{ }^{20}$ The driving force of this Institute, Tomàs Carreras i Artau, influenced by Scottish-British theories on "common sense", saw its purpose in building a team to analyze all expressions of the "collective Catalan Spirit»." Most answers to those questionnaires were lost during the Civil War, before having led to publications, but the process itself was valuable, since it created a spirit of cooperation between Catalans in the city and in the country, between simple citizens and professors, in a brotherhood of Catalans rediscovering and reviving their common cultural heritage. Everyone involved felt like the priest from Vilajuiga, who sent in the goig of his local saint, adding: "God bless your work... if its purpose is to rebuild our Countrys."

Singing in choirs also became a cultural activity with symbolic values for Catalans. ${ }^{23}$ The male choirs founded by Anselm Clavé, of

19 Usos $i$ costums del bon pagès sobre boscos $i$ arbredes, Barcelona 1920 (repr. 1980); Costums sobre termenals, camins $i$ aigües en terra de pagès, Barcelona 1921.

${ }^{20}$ See Calvo 1991. The list is reproduced in Calvo 1990, and in Prats 1982, pp. 63-65. Questionnaires on folklore have a long tradition. Answers to one prepared by Francisco de Zamora in 1790 submitted by over twenty villages in North-Western Catalonia, are being reprinted by R. Boixareu, Pep Coll and M. Bonete in Lleida, 1969, 1989, 1990, 1991. Research by questionnaire continues today, Between 1981 and 1983 the Generalitat asked all priests in charge of hermitages for a set of data.

"21 "La espiritualidad colectiva catalana", quoted in Calvo 1991, p. 116.

${ }^{22}$ "....la restauració de nostra Pàtrios, quoted in Calvo I991, p. 116.

${ }^{23}$ See Pere Artís i Benach, El cant coral a Catalunya (I89I-I979), Barcelona 1980. 
which there were eighty-five in 1864 , had the purpose to slead workers to higher values through the brotherhood of musi". They lost much of their appeal after of the death of Clavé, but then Lluís Millet founded new, mixed choirs, more congenial to the conservative urban middle class. Their organizers were convinced that "The Orpheons are reviving through music the singers' consciousness of being Catalan", or, in a more recent wording, that they are engaged in "the peaceful struggle to gain a more complete national identityn., The repertoire of these choirs leaned heavily to patriotic songs. One, for instance, recounts the legendary origin of the quatre barres, the four red bars on a gold ground of the Catalan flag. Another traditional song became the national anthem, the Segadors, declared official only in January of 1993. ${ }^{25}$ To sing it during mass assemblies, especially in places with a symbolic meaning in Catalan history, is a very emotional experience for singers and listeners alike. The prohibition to intone it at two interregional choir meetings in I9I9 and in I920, led to public disturbances, just as happened with concerts in Barcelona at the Palau de la Música in 1960 and 1967, when the inclusion of the song in the programs, which had been approved in advance, was withdrawn at the last minute on orders from the Governor.

Interregional gatherings of associations are also very frequent in the case of dancers of the sardana. ${ }^{26}$ This dance was originally just one of many from the region of the Empordà. It was taken up in Barcelona, and then by all Catalonia, after about 1860 , but took on symbolic connotations of nationalist demands only after it was proscribed by Franco. To keep excursionists from dancing it somewhere in the

The 199 I centenary of the Orfé was judged worthy of a commemorative postage stamp, the tasteless design of which was considered by many Catalans a deliberate act of ridicule from Madrid.

${ }^{24}$ Quotations translated from Artís, p. 47.

${ }^{25}$ See J. Massot i Muntaner, ed., Els segadors. Himne nacional de Catalunya, Barcelona: Generalitat, I983.

26 The most recent history of the sardana is by Josep Mainar, 1986. See also Barrera, pp. 300 ss., and Stanley Brandes, The Sardana: Catalan Dance and Catalan Identity, 1985 and 1990. 
countryside was, however, impossible, and to disallow it during the festivities of the enthronment of the statue of the Virgin Mary on Catalonia's holy mountain of Montserrat in 1947 would have been politically unwise. Gatherings of sardanistes became a yearly event on Montserrat after 1952. In 1960 a special "Day of the sardana" was declared for all of Catalonia, with one city being honoured as pubilla de la sardana. ${ }^{27}$ In 1966 the idea was added that every year a symbolic flame should be carried from one pubilla-city to the next, with frequent dancing along the way. At the immense gathering of dancers in Barcelona in I979 to celebrate the new autonomy-granting Constitution, orators congratulated the sardanistes on having «kept the faith». The audience, having learned during the many years of censorhip to read between the lines, knew that the speakers alluded not just to the faith in the return of the freedom to dance sardanas —or to sing or talk in Catalan at public functions, or to publish the newsletters of their clubs in Catalan - but to the faith in an independent Catalonia.

\section{MODERN FOLKLORIC EXPRESSIONS OF CATALANISM:} GOVERNMENT SUPPORT AND ACADEMIC RESEARCH

While hikers, singers and dancers were able to bridge the dark years of Franco's reign, the academic institutions which traditionally have studied such activities find it difficult to pick up the pieces where folklorists were forced to leave theim in 1939. The great initiatives by the Mancomunitat and the Catalan Republic were paralyzad during the dictatorship of Primo de Rivera, and then nearly destroyed under Franco. The "Arxiu d'Etnografia i Folklore de Catalunya" was incorporated in 1945 into the central administration of the "Consejo Superior de Investigaciones Cientificas» where it withered away until its

27 The best translations of pubilla would be "Queen" or "Princess", since the literal "Heiress" does not carry in English the symbolic charge of the name given to the bride of the oldest son, heir to the whole family estate, in a legal system which is considered the cornerstone of Catalan rural peace and prosperity. 
dissolution in 1968. The long awaited official Museum of Catalan Ethnography - proposed to the Mancomunitat in 1920 as a monument a la raça- opened in 1940 as "Museo de Industrias y Artes Populares" in Barcelona's touristy "Pueblo Español». Professors of "Peninsular Ethnologyn in those years were obliged to present Catalan folklore as a regional contribution to the rich mosaic of Spanish rural life.

The fact that so much of value was written along traditional lines about Catalan folklore in the Forties' and Fifties' is entirely due to the personal perseverance of two exceptional personalities outside of academic circles: Ramon Violant i Simorra († 1956$)^{28}$ and Joan Amades († 1959). ${ }^{29}$ Specialists might question their methods, but the enthusiastic public reception of their publications shows that Catalans relive in them that espurna patriotica, that exciting dream of nationhood, which was already at the roots of the excursionisme cientific of their grand-parents. Both appealed to the general reader with abundant reproductions of popular imagery, reprints of folksongs, riddles, shepherd's lore and the like. They never doubted the relevance or validity of their research. Some Catalans might have bought their publications just to show support for patriotic researchers and publishers during the lean years of Franco's dictatorship, but the editorial success even of expensive coffee-table books on rural ceramics or furniture, regional markets and festivities, and so on, shows that there is still much public interest in traditional folklore. ${ }^{\text {so }}$ Some regional compilations of

${ }^{28}$ See Prats 1980.

29. See note 2 and Bibliography. We would also like to mention Valeri Serra i Boldú († 1938), main force behind the Arxiu de Tradicions Populars (1928-1935, facsimile Barcelona 1980) and author of several monographs now being reprinted by Montserrat (e.g. Folklore de la pagesia, 1987), and Josep-Maria Casacuberta († 1986), editor of the "Biblioteca folklórica Barcino" (twelve volumes, 1952-1955) and publisher of Joan Lluís' El meu Pallars (four volumes, 1959-1979).

30. Ediciones 62, for instance, has a series on "Vida $i$ costums dels catalans", with volumes on folk art, rural architecture, popular traditions, village markets and traditional food. (This last book's subtitle is a political manifesto: Crònica de la resistència dels senyals d'identitat gastronòmica catalana.) Destino publishes "Imatges de Catalunyaw, on village feast days, rural estates, the Pyrenees, the Costa Brava, Catalan cloisters, the Montseny, Montserrat. Nou Art Thor offers the series "Terra Nostra", with volumes 
folkloric material are kept in print, even if their value is doubtful." Museums with exhibits of traditional tools and artifacts are opening, or reopening, everywhere, ${ }^{32}$ and country fairs or feasts of local saints $s^{33}$ are more often than not hopelessly overcrowded. Activities which traditionally accompanied such celebrations are being revived or strengthened, for instance the building of castells, with up to nine levels of men and boys standing an each others' shoulders, ${ }^{34}$ the procession of giants, ${ }^{35}$ dwarfs and big-heads, the cercaviles of musical bands promenading through narrow streets, dances of bastoners using sticks to beat the rhythm, and the activities of front-end loaders, firebreathing mythical beasts, ${ }^{36}$ devils, and many other groups.

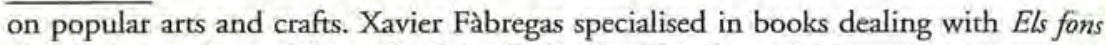
rituals de la vida quotidiana, the title of a book of his from 1981.

${ }^{3 i}$ For instance, Joan Moreira, Del folklore Tortosi, Tortosa 1934, 1979 (720 pp.); Joaquim Pla Cargol, Tradiciones... santuarios y tipismo de las comarcas gerundenses, Girona 1946, 4a ed. 1957; Ramon Violant i Simorra, Etnografia de Reus $i$ la seva comarca, Reus 1955-1959, repr. Barcelona 1990.

${ }^{32}$ See the yearbook "De Museus" published, since 1988 , by the Generalitat through its "Servei de Museu" and a series of articles in "L'Aven $\rho$ ", vols. 28-37, 1980$198 \mathrm{I}$ (e.g. on the Wheat growers' museum in Cervera, or the Wine museum in Vilafranca). The bank "La Caixa", subsidizing such activities, published a Guia dels museus de Catalunya (Barcelona 1979). See also the Generalitat's. Inventari del patrimoni arquitectònic de Catalunya, vol. r: El Ripollès, 1985, vol. 2: L'Alt Penedès, 1986, and Catàleg de monuments $i$ conjunts històrico-artistics de Catalunya, 1990 (463 Pp.).

${ }^{33}$ Over eight thousand such celebrations are listed in the excellent Calendari de festes de Catalunya, Andorra i la Franja, published by the "Fundació Serveis de Cultura Popularn, Barcelona 1989 (631 pp.; volumes on Valencia, the Balearic Islands and the Catalan speaking valleys of Southern France are to follow). Illustrated publications on rural festivities are likely to remain popular; for instance Capmany I95I (repr. 1978-1982), Fábregas 1975, Casassas 1978, Soler i Amigó 1979. For Girona, see Anon., La festa a les terres de Girona, Girona: Diputació, 1991.

${ }^{34}$ See the two volumes Món casteller, Barcelona 1981-1982 (1646 pp.) written mostly by Pere Català i Roca. To build sech human towers one needs, according to the Casteller's Manifesto, the "typical Catalan qualities" of força, equilibri, valor, seny. See also Fina Duran, Petita història dels castellers, Valls 1990.

${ }^{35}$ Seen Anon., Gegants, a pictorial inventory of one hundred giant-like walking figures.

${ }^{36}$ Such as the patum from Berga. The concluding ceremonies of the 1992 Olympics offered an impressive demonstration of the use of fire in Catalan folklore. 
"Popular culture» has become the umbrella term for an ever widening range of human endeavours, from sheep shearing in the Pyrenees to keeping youngsters off the streets with puppet shows. Scholars investigating such activities do not try to find a common denominator for them all, not wishing to repeat the romantic fallacy of seeing a unique Catalan-ness behind everything done by native speakers of Catalan. The two major institutions organized recently by the Generalitat in relation to "popular cultture" avoid a preconceived frame of reference and ideological motivation and would resent all insinuations that they wish to reintroduce old myths and symbols; in short, the proverbial espardenya and the barretina, the sandals and headwear of yesteryear's peasants. The "Centre de Documentació i Recerca de la Cultura Tradicional i Popularn, ${ }^{37}$ founded in 1983 in response to the great expectations created by the "First Convention on Popular and Traditional Culture ${ }^{38}$ sees its function as an archive of materials bequeathed to them by Joan Amades and other formerly private collections. The "Fundació Serveis de Cultura Popular»" simply wants to «bring culture to those who have no access to it». It supports all kinds of projects proposed to it in yearly competitions. Its purpose is not to support the shepherd in the Pyrenees nor to put on a puppet show, but it will subsidize making a video about sheepshearing or organizing a wokshop for puppeteeers. None of this is done for the ideological purpose of

37 The CDRCTP will probably become the «Centre de Promoció de la Cultura Popular i Tradicional Catalana" announced in the "Llei de Foment i Protecció de la Cultura Popular i Tradicional i de l'Associacionisme Cultural" from December 2, I99I.

${ }^{38}$ The Generalitat published in 1983 a Memòria about this convention and, in 1986, Jacqueline Hall's English summaries of its deliberations. The CDRCTP has announced plans to publish a journal with the title "Recerca i Difusió de l'Etnologia Catalandr.

39 Since 1987 the FSCP has published yearly a Memòria d'activitats, with lists of radio programs, videos, youth festivals and other activities which it helped get started. In its series "Col-lecció Cultura Popular" it published the proccedings of a I98I symposium on La cultura popular a debat (see Llopart 1985). In this volume compare one speaker's criticism of the Generalitat's "populisme folklòrio" (pp. I92-202), with another's defense of "La dinamització cultural desenvolupada per la Generalitat de Catalunya (1980-1984), (pp. 203-214). 
fomenting patriotism. This might not be necessary, since most participants in such projects are driven by the desire to do something for their neighborhood, for their town, for the children, for the immigrants, the jobless, the drug-addicts, but they want to do it in Catalan, as Catalans. Few see themselves as continuators of last century's organizations, but there are surprising parallelisms. Clavés choirs wanted to offer workers an alternative to taverns; ateneus and neighborhood libraries were opened to prepare the illiterate for jobs; hiking clubs socialized underpriviledged children. The old excursionisme cientific was motivated by ideals which today seem suspect. But marches in the country were still the most natural form expression for Father Xirinac's non-violent protest movement in 1976 to attract attention to the plight of political prisoners in Spain. ${ }^{10}$ The excursionism of the 19th century and the protest movements of the Seventies' seem to have little in common with the new network of long-distance hiking trails covering all of Catalonia, ${ }^{41}$ or the recent phenomenon of mass marathons and night marches, ${ }^{42}$ but a spirit of Catalan pride animates the organizers and the participants alike, and all such activities have the potential to take on ideological values.

Excursions to places having religious or historical connotations for Catalans remain the activity most strongly charged with symbolism. When in 1950 Father Antoni Clavet was canonized, a sizable group of excursionists spent a night around a fire under the cross Clavet had placed on top of the Montseny. From then on, every tenth of July, the excursion was repeated, and the guardia civil had to look on while

$4^{\circ}$ See Barrera, p. 292. On protest songs see the Antologia Nova Cançó by Manuel Vàzquez, Barcelona 1968. On the other hand, in 1978 a group of Barcelonese youth which travelled through all four Catalans speaking regions in horse-drawn flag-covered wagons were met with hostility when they ventured outside of Catalonia proper. See Barrera, p. 293, and Anon., La volta en carro.

${ }^{4 t} \mathrm{~A}$ folder on these $3000 \mathrm{~km}$ of trails is distributed by the Generalitat, proud to be "the pionner of Peninsular long-distance hiking". Detailed guidebooks are published by Montserrat.

${ }^{42}$ See the index of the Calendari mentioned in note 33, under marxes, traverses, curses, pujades, excursions. 
mass was celebrated in Catalan, a sardana was danced, and every participant had quatre barres stuck somewhere on his or her backpack. In 1955, inspired by a poem by Verdaguer, hikers from Catalonia and the Roussillon spend the night of June 22 on the Canigó. ${ }^{43}$ A few years later, a torch lit at a similar fire was carried to the French-Spanish border and placed in the center of a ring of sardana dancers. The flame was multiplied and carried to Perpinyà in the North and to Vic and other places in the South. The direction is now often reversed: Hikers take the flame from Perpinyà to the top of the Canigó on the vigil of Saint John's and from there it is carried to all four Països Catalans. The symbolism of a united Catalan Nation from Salses to Guardamar and from Fraga to Maó - the four cities in the four "corners" of the Catalan speaking region - is quite patent, linked with the chtonic forces of dances around fires on mountain tops at summer solstice.

Such heavy symbolism can also be found in activities related to the Catalan language. To celebrate the centenary of the birth of Pompeu Fabra, the masterminds behind the standardization of Catalan orthography who died in exile in Prada, excursionists hiked in 1968 to his grave, lit a flame and carried it to Montserrat. ${ }^{44}$ On the way they stopped at the convent of Sant Miguel de Cuixà - the cloister of which is now the museum The Cloisters in New York- where four priests, representing the four Paisos Catalans, read mass. In Montserrat thousands were waiting for the arrival of the "Flame of the Catalan language". After it had been placed in a lantern with the inscription «Faith lit it - Perseverance brought it this far - The Will of the people keeps it alive», ${ }^{45}$ they all sang patriotic songs and danced the sardana. This perennial flame became yet another incentive for associations to make an excursion to Montserrat. Many invented new ways to bring a flame or to take one home. For instance, in 1978, four groups convened there

43 See Barreta, p. 294.

44 See Barrera, p. 296.

45 Our translation. Notice that «ib" can stand for "flame" or "languagen, permitting a religious or a geographic and historical reading of the inscription ("carried the torch to Montserrat" vs. «kept the language alive though the Franco years"), 
with torches lit at Fabra's grave in "Catalunya Nord", at Ausiàs March's grave in València, at Ramon Llull's tomb in Palma de Mallorca and at James I's sarcophagus in the royal abbey of Poblet.

For Catalans who prefer less religious connotations at their patriotic outings, there has been since 1980 the yearly meeting under the "Pine with the three branches" on the Plains of Campllong, ${ }^{46}$ where, according to a myth sung by Verdaguer, James I assembled his knights before setting out to forge Catalonia, the Balearic Islands and Valencia into one nation. In 1983 a twig from the Pi de les tres branques was carried to the Flama de la llengua in Montserrat, lit there, and distributed to excursionists from all the regions where Catalans is spoken.

\section{CONCLUSION}

With this danger of repetitiousness and saturation, such happenings no longer make the news. Now that the old freedom of association, with flags, songs and dances, has been regained, what practical purpose do such outbursts of patriotic sentimentalism have? The heavy ideological discourse behind last century's choirs, hiking clubs, reading circles, dance groups - and even associations of philatelists, vegetarianswhich were all encouraged to see themselves as expressing basic and perennial values of Catalan individuality and distinctiveness, has become impossible in our more sophisticated world. ${ }^{47}$

The romantic notion of the shepherd from the Pallars, the char-

${ }^{46}$ For a picture of this tree see Ramon Vinyeta, Els arbres monumentals de Catalunya, Torelló 1985 , p. 10, with a map of how to find the pi de les tres branques.

47 We observe, however, how books for children are again unabashedly romanticizing Catalonia's past. In I990 Barcanova complemented its series on "World Mythologies" with an illustrated volume on Mitologia catalana by Joan Soler ( 2 a ed. 199I), which retells the myths of Montserrat, Count Arnau, Sant Jordi, the "quatre barres", and the "Pi de les tres branques". Maria G. Espadaler, in Els origens de Catalunya (1989), invites her young readers to see in the vaguely triangular outline of Catalonia's borders the symbolic value of the Trinity and of timelessness (intemporalitat, p. 9). 
coal maker from the Montseny and the fisherman from Cambrils as depository of the true Catalan national identity was dubious all along - except, maybe, from a linguistic point of view - but it gave strength to a patriotic movement which has led to social and political achievement during the Mancomunitat and the Catalan Republic still not equalled by the autonomous Generalitat. It seems that even today's pragmatic generation needs the dream of national identity to give it the political will to work towards solving the myriads of problems of modern society; the dream and hope of assuring a better future for ther country, for their country, Catalonia. Symbols for Catalan national unity no longer have to be invented. But the ways they are expressed are changing, and probably must keep changing. They are being incorporated, through the medium of the Catalan language, in the many ways basic human needs are being fulfilled: the need for leisure and entertainment in song and dance, the need for social interaction in associations of all kinds (for instance for fans of the soccer club el Barça which is "more than just a club"), ${ }^{48}$ the need for mental stimulation in schools, ${ }^{49}$ museums, the media, libraries, the need for spiritual reassurance in religious ceremonies, the need for expressing oneself in one's native tongue, the need for a feeling of belonging to a community which shares one's own sense of history and destiny.

The activities which contribute to the fulfillment of these needs are not easily classified. No wonder academic circles are unsure if they are the domain of folklorists, ethnographers, anthopologist or social scientists. It matters little. As long as academics want to remain just objective observers, they will not become formers of opinions and behaviour. Whether the various popular «folklorio organizations in Catalonia and their activities can again be motivated to act as forces in a drive to political independence, will depend as much on their members as on today's

$4^{8}$ See Jaume Sobrequés i Callicó, F. C. Barcelona, un club al servei de Catalunya, Barcelona: Labor, 1991.

49 Gabriel Janer Manila, in his Cultura popular i ecologia del llenguatge, Barcelona 1982 , strongly recommends the use of folkloric materials in schools "per raons nacionals... la recuperacipó de la nostra indentitat col-lectivan. 
political leaders. Leaders who during the Catalan religious national holiday of Sant Jordi on April 23, or on the political national holiday on September nth, or at rallies under the Pi de les tres branques ${ }^{\circ}$ do not just repeat the words of the great nation-builders Prat de la Riba, Almirall, Pi i Margall, Batista i Roca, but who truly believe in them and are themselves driven by them. On March 5th 1993 the Government of Catalonia has introduced the "Llei de foment i protecció de la Cultura popular i tradicional i de l'associonisme cultural" which will allow extensive official support for activities of the kind described in this article. The Government will be advised by a "Consell de Cultura Popular i Tradicional». For more information see the journal "Cultural" 46, June 1993.

CURT WITTLIN UNIVERSYTY OF SASKATCHEWAN'

\section{BIBLIOGRAPHY}

AINAUD DE LASARTE, Josep Maria, Simbols de Catalunya, in La Naixença de Catalunya. (Nadala de la Fundació Jaume I), Barcelona: Barcino, 1979, Pp. 53-II5.

AMADES, Joan, Costumari catalá, El curs de l'any (five volumes, 5031 pp.), Barcelona: Salvat, 1950-1956 (repr. Selecta, 1982-1984).

-. Folklore de Catalunya (three volumes, 4525 pp.), Barcelona: Selecta, 1950-1969.

Anon., Gegants. Aportació de Matadepera al nostre folklore, Matadepera: Caixa d'Estalvis, 1982.

-. Introduction by Josep Maria Espinàs), La volta en carro als Paüsos Catalans, Barcelona: La Magrana, 1980 (3rd ed. 1987).

ARTís I BENACH, El cant coral a Catalunya (I89I-I979), Barcelona: Barcino, 1980.

50 For pictures of such celebrations see the 1978 Nadala (nadales are books especially printed as Christmas presents) distributed in 25,000 copies by the Fundació Jaume I, Pp. 53-II5. 
-. L'Obra del Cançoner Popular de Catalunya, "Revista Musical Catalana» 3 (1986), 696-616. (Cf. Massot, 198I).

"Arxiu d'Etnografia de Catalunya", vol. I (1982), pp. 79-106 on paremiology, pp. I09-176 on research guides; vol. 2 (1983), PP. 13I-170 on religion; vol. 3 (1984), pp. 139-172 on immigration.

Barrera, Andrés, La dialéctica de la identidad en Cataluña. Un estudio de antropologia social, Madrid: Centro de Invest. Soc., 1985 (esp. pp. 289-3I2).

BASTARDAS I PARERA, Albert, Les creus al vent, Barcelona: Millà, $x 983$ (407 photographs; cf. Gudiol).

BRANDES, Stanley H., La sardana como símbolo nacional catalán, "Revista de Folklore» 59, Valladolid 1985. - In English: The Sardana: Catalan Dance and Catalan National Identity, "Journal of American Folkloren 103 (1990), 24 ss.

Calyo Calvo, Lluís, Catàleg de materials etnogràfics de l'Arxiu d'Etnografia i Folklore de Catalunya, Barcelona: CSIC, I990.

-. El "Arxiu d'Etnografia i Folklore de Catalunya» y la Antropologia catalana, Barcelona: CSIC, 199I (extract of his dissertation on La Antropologia en Cataluña, 1915-1970).

CaPMANY, Aureli, Calendari de llegendes, costums i festes tradicionals catalanes, Barcelona: Laia, 195I (repr. 1978-1982).

CASASSAS I SIMÓ, Lluís, Fires $i$ mercats a Catalunya, Barcelona: Edicions 62, 1978.

CATAl.A I Roca, Pere (main contributor), Món casteller, 2 vol. (6ro and 1036 p.), Barcelona: Rafael Dalmau, 198i-1982.

Centre de Documentació i Recerca de la Cultura Tradicional i Popular, El món de Joan Amades, Barcelona: Generalitat, 1990.

COCCHIARA, Giuseppe, The History of Folklore in Europe, Philadelphia 1981. (Italian original, Torino 1952 , reed. 1971.)

COSTA I SAVOIA, Ernest, Viatges amb els pastors transhumants per les cabaneres de la Catalunya nord-occidental, Barcelona: Centre Excursionista, 1987.

FABREGAS, Xavier, Cavallers, dracs i dimonis. Itinerari a través de les festes populars, "Catalunya Visió» 12, Montserrat 1976.

FRIGOLÉ, Joan, Inversió simbòlica i identitat ètnica. Una aproximació al 
cas de Catalunya, "Quaderns de l'Institut Català d'Antropologia" I (I980), 2-27.

Fundació Serveis de Cultura Popular, Calendari de festes de Catalunya, Andorra i la Franja, Barcelona: Altafulla, 1989 (63I p.). Generalitat de Catalunya, ed., Excursionisme i Cultura: Cinquè congrés excursionista català: Comunicacions presentades, Barcelona 1982. - Memòria del Primer congrés de Cultura Tradicional i Popular, Barcelona 1983. (Cf. Hall).

-, Resums de les communicacions presentades al Congrés de Cultura Tradicional i Popular, 2 vol., Barcelona 1981. (Cf. Hall).

Gudiol I Cunill, Josep, Les creus monumentals de Catalunya, Barcelona: Centre Excursionista de Catalunya, 1919. (Cf. Bastardas).

Hall, Jacqueline, The Congress of Catalan Tradition and Popular Culture (1981-1982), Barcelona: Serveis de Cultura Popular, 1986. (cf. Generalitat).

HовSваWм, Eric J., et al., The invention of Tradition, Proceedings from a 1977 convention; Cambridge 1983. (Catalan translation, Vic: Estudis Universitaris, 1988).

IGLÉSIES, Josep, Història (1876-1939) and Història (1940-1965), in Enciclopèdia de l'excursionisme 1, p. 17-714, and 2, p. 5-246, Barcelona: Rafael Dalmau, 1964.

LlOBERA, Josep R., La formació de la ideologia nacionalista catalana, "L'Avenç" 36 (1983), 24-35.

- La idea de Volksgeist en la formació de la ideologia nacionalista catalana, dins Història i Antropologia: A la memòria d'Angel Palerm, Montserrat 1984, p. 403-423.

LloparT, Dolors, et. al., La cultura popular a debat, Proceedings of a 1981 colloqium; Barcelona: Serveis de Cultura Popular, 1985 .

-, Aproximació bibliogràfica als estudis etnològics del Pirineu català, "Quaderns de l'Institut Català d'Antropologia» 2 (1980), IOI-I52.

MaINAR, Josep, La Sardana. Dansa nacional, dansa viva, Barcelona: Rafael Dalmau, 1986.

Massot i Muntaner, Josep, Marià Aguiló, col-lector de cançons populars, dins Actes del cinquè col-loqui internacional de llengua i literatura catalanes. Andorra 1979, Montserrat 1980, p. 287-324. 
- Marià Aguiló i la poesia popular, dins Homenatge Casacuberta vol. 2, "Estudis de Llengua i Literatura Catalanes" 2 (I98I), 307-332.

-, et al., Els Segadors. Himne nacional de Catalunya, Barcelona: Generalitat, 1983.

Puigjaner, Josep Ma, Conèixer Catalunya, Barcelona: Generalitat, 1990. PRAT, Joan, El folklore catalán: ¿Ideologia o ciencia?, dins Actas del segundo congreso de Antropologia, Madrid 1985, p. IIO-I20.

- Mites $i$ estereotips de la identitat, dins Encontre d'Antropologia i diversitat hispànica, Barcelona: Generalitat, 1988, p. 169-178.

-, Els estudis etnogràfics i etnològics a Catalunya, "Quaderns de l'Institut Català d'Antropologiaw I (1980), 28-63.

-, Algunas consideraciones sabre el simbolismo catalán, dins Actas del Primer congreso español de Antropologia. Barcelona 1977, Barcelona: Universidad, 1980, p. 527-553.

-, (coordinator), Trenta anys de literatura antropològica sobre Espanya, "Arxiu d'Etnografia de Catalunya" 4-5 (1985-1986), p. 9-43, Introduction (followed by Spanish and English translations).

PRATS, Llorenç, La transición del folklore a la etnografia en Cataluña. La obra de Ramon Violant i Simorra, "Ethnica" I6 (I980), I05-120. -, L'estudi històric de les formes de vida popular a la Catalunya contemporània (s. XIX), dins Simposi d'Antropologia cultural sobre Xavier Fàbregas, Montserrat 1990, p. 37-55.

-, El mite de la tradició popular. Els orígens de linterès per la cultura tradicional a la Catalunya del segle XIX, Barcelona: Curial, 1988.

-, et al., La cultura popular a Catalunya. Estudiosos i institucions (1853-1981), Barcelona: Serveis de Cultura Popular, 1982.

PUJADES, Joan, Antropologia catalana o Antropologia a Catalunya. Tradicions $i$ nous enfocaments, "Arxiu d'Etnografia de Catalunya" 2 (1983), 73-94. (Reprint from "Butlletí de la Fundació Jaume Bofilln 1982.)

-, Identitat catalana i simbols culturals, "Ciència» IS.

RAMON I VIDAL, Jaume, L'excursionisme, un fet sociah, Barcelona: Unió Excursionista de Catalunya, 1983.

ROMA, Josefina, Etnografia y folklore en Cataluña, in A. Aguirre, ed., La antropología cultural en España, Barcelona 1986, p. I6I-183. 
ROQUE, Maria Àngels, coordinator, Encontre d'Antropologia i diversitat hispànica, Barcelona: Generalitat, 1988.

SEgARRA, Antoni, Fires i certàmens agraris de Catalunya, Barcelona: Institució Catalana d'Estudis Agraris, 1991.

TORRES I MESTRE, Estanislau, Escursionisme i franquisme, "Llibre de motxila", IO, Montserrat 1979.

ViOLANT I SimORRA, Ramon, Obra Oberta, four volumes of reprints, Barcelona: Altafulla, 1979-1981. 